\title{
GEOMORPHIC EVOLUTION OF WESTERN (PALIKI) KEPHALONIA ISLAND (GREECE) DURING THE QUATERNARY
}

\author{
Gaki - Papanastassiou K. ${ }^{1}$, Karymbalis E. ${ }^{2}$, Maroukian H. ${ }^{1}$ and Tsanakas K. ${ }^{1}$ \\ ${ }^{1}$ University of Athens, Faculty of Geology and Geoenvironment, Department \\ of Geography and Climatologyy, 15771 Athens, Greece \\ Emails:gaki@geol.uoa.gr,maroukian@geol.uoa.gr,ktsanakas@geol.uoa.gr \\ ${ }^{2}$ Harokopio University, Department of Geography, 70 El. Venizelou Str. 17671 Athens, Greece \\ Email:karymbalis@hua.gr
}

\begin{abstract}
Kephalonia Island is located in the Ionian Sea (western Greece). The active subduction zone of the African lithosphere submerging beneath the Eurasian plate is placed just west of the island. The evolution of the island is depended mostly on the geodynamic processes derived from this vigorous margin. The geomorphic evolution of the western part of the island (Paliki peninsula) during the Quaternary was studied, by carrying out detailed field geomorphological mapping focusing on both coastal and fluvial landforms, utilizing aerial photos and satellite image interpretation with the use of GIS technology. The coastal morphology of Paliki includes beachrocks, aeolianites, notches and small fan deltas which were all studied and mapped in detail. The drainage systems of the peninsula comprise an older one on carbonate formations in the northwest and a younger Quaternary one in the south and southeast. Eight marine terraces found primarily on the Pliocene marine formations range in elevation from $2 \mathrm{~m}$ to $440 \mathrm{~m}$ are tilted to the south. In the Late Pleistocene some of the main drainage networks flowed towards the newly-formed gulf of Argostoli to the east.
\end{abstract}

Key words: drainage networks, marine terraces, geomorphology, Paliki peninsula, Kephalonia island, Quaternary.

\section{Introduction}

The study area, the Paliki peninsula, is located in the western part of the island of Kephalonia which occupies an important position along the Hellenic arc system (Fig. 1). Paliki peninsula exhibits many geomorphic features which reflect the active tectonic regime of the area.

The aim of this work is to examine the geomorphological evolution of the area during the Quaternary based on the study of different geomorphic indicators. The most important among them are a series of uplifted and tilted marine terraces, notches, beachrocks, aeolianites, drainage systems, knickpoints, gorges and fluvial terraces. These geomorphic indicators were studied through detailed geomorphic mapping and extensive field-work.

For this purpose topographic diagrams at a scale of 1:5000 obtained from the Hellenic Military Geographical Service were used in the field. Additionally a spatial database was constructed derived from analogue topographic maps at various scales (1:50000 and 1:5000), geological maps (1:50000 map of IGME and 1:100000 map of BP Co Ltd) aerial photographs and satellite images using GIS 


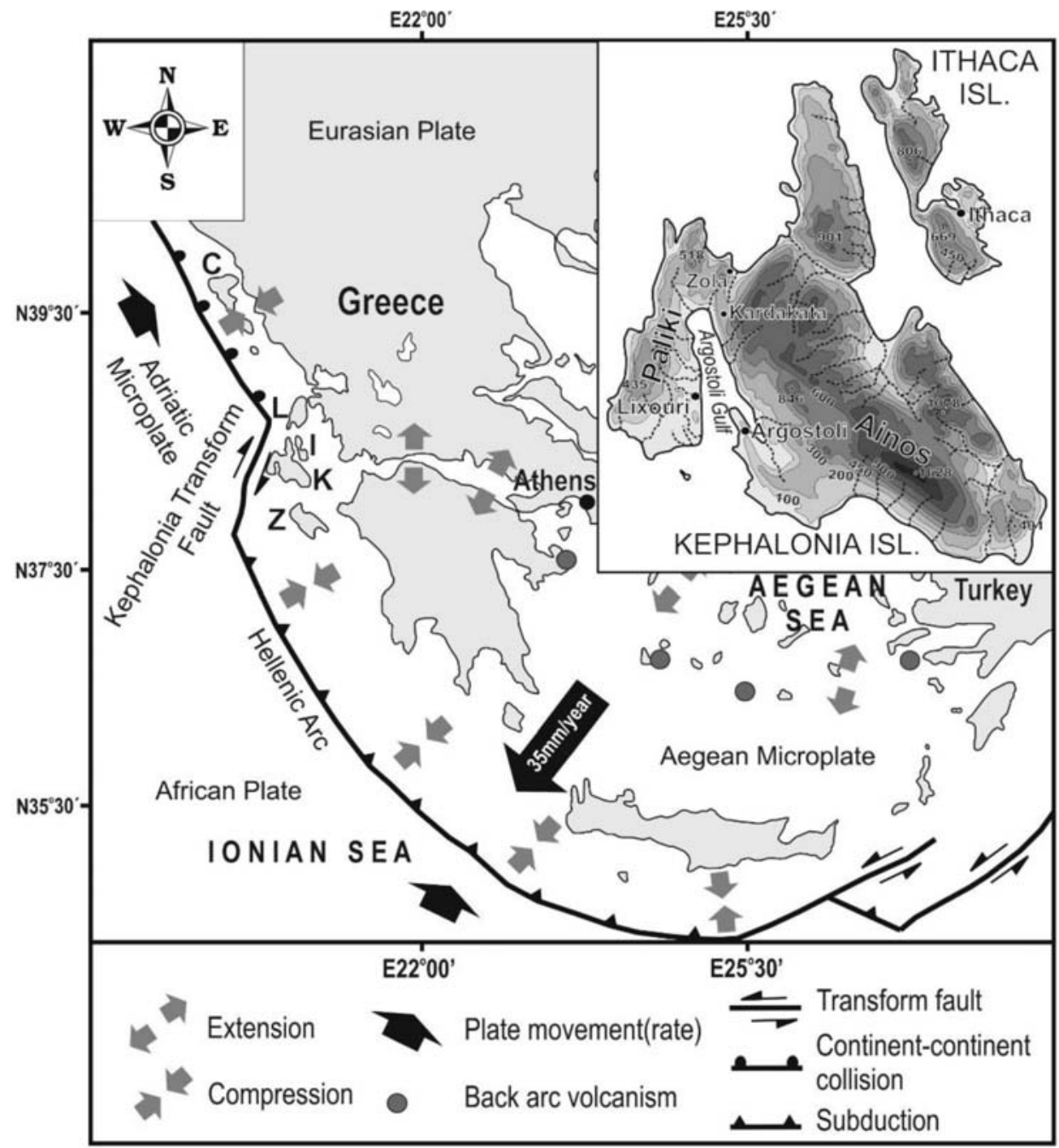

Fig. 1: Location map of the Ionian islands and the geodynamic setting of the broader area of the Aegean. Letters C, L, K, I, and Z stand for the islands of Corfu, Lefkada, Kephalonia, Ithaca and Zakynthos respectively.

techniques. Data procedure in the analytical context of GIS provided data integration including a common geographical reference system, common spatial and temporal coverage with similar scale and quality of the data.

\section{Geology, tectonics and seismology of the area}

The geodynamic processes in the region are related to the active subduction of the African lithosphere beneath the Eurasian plate, which progressively becomes continental convergence in north-western Greece (Fig. 1). The transition occurs along the Kephalonia Fault Zone (KFZ) a prominent dextral strike slip fault, located offshore west of Kephalonia and Lefkas islands (Scordilis et al., 1985; Louvari et al., 1999). 


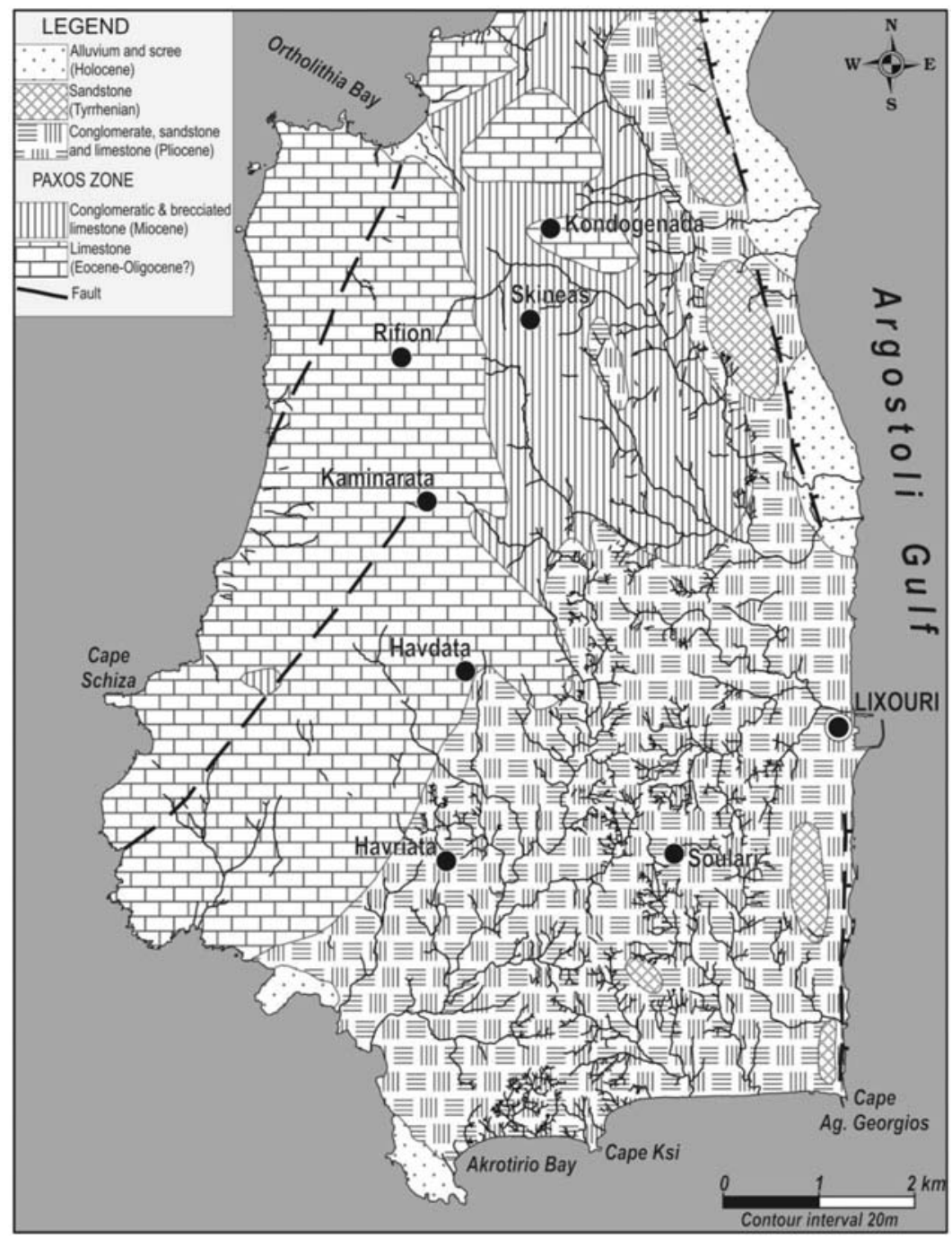

Fig. 2: Simplified geological map of the study area based on the maps by B.P (1971) and IGME, (1985) and detailed field work.

The basement of the island consists of east dipping, NW to NNW striking, thrust sheet fragments of a carbonate platform belonging mainly to the Paxos geotectonic zone (Underhill, 1985, 1989). The Ionian zone is also present occupying a relatively small area in the eastern part of the island.

The alpine basement of the Paliki Peninsula belongs to the Paxos geotectonic zone (BP Co Ltd, 1971; IGME, 1985). The older formations outcropping in the study area are Eocene-Oligocene limestones overlain by conglomeratic and brecciated limestones of Upper Oligocene to Upper Miocene age. The basement is overlain by Pliocene marine deposits. In the Lower Pliocene there is a short stratigraphic hiatus and a transgressive well-bedded conglomeratic facies. Near the base there is a limestone bed passing upwards into sand, sandstone and sandy limestone with layers of marls. Upwards, the blue marls predominate and enclose a rich mollusc fauna while in the uppermost part a 


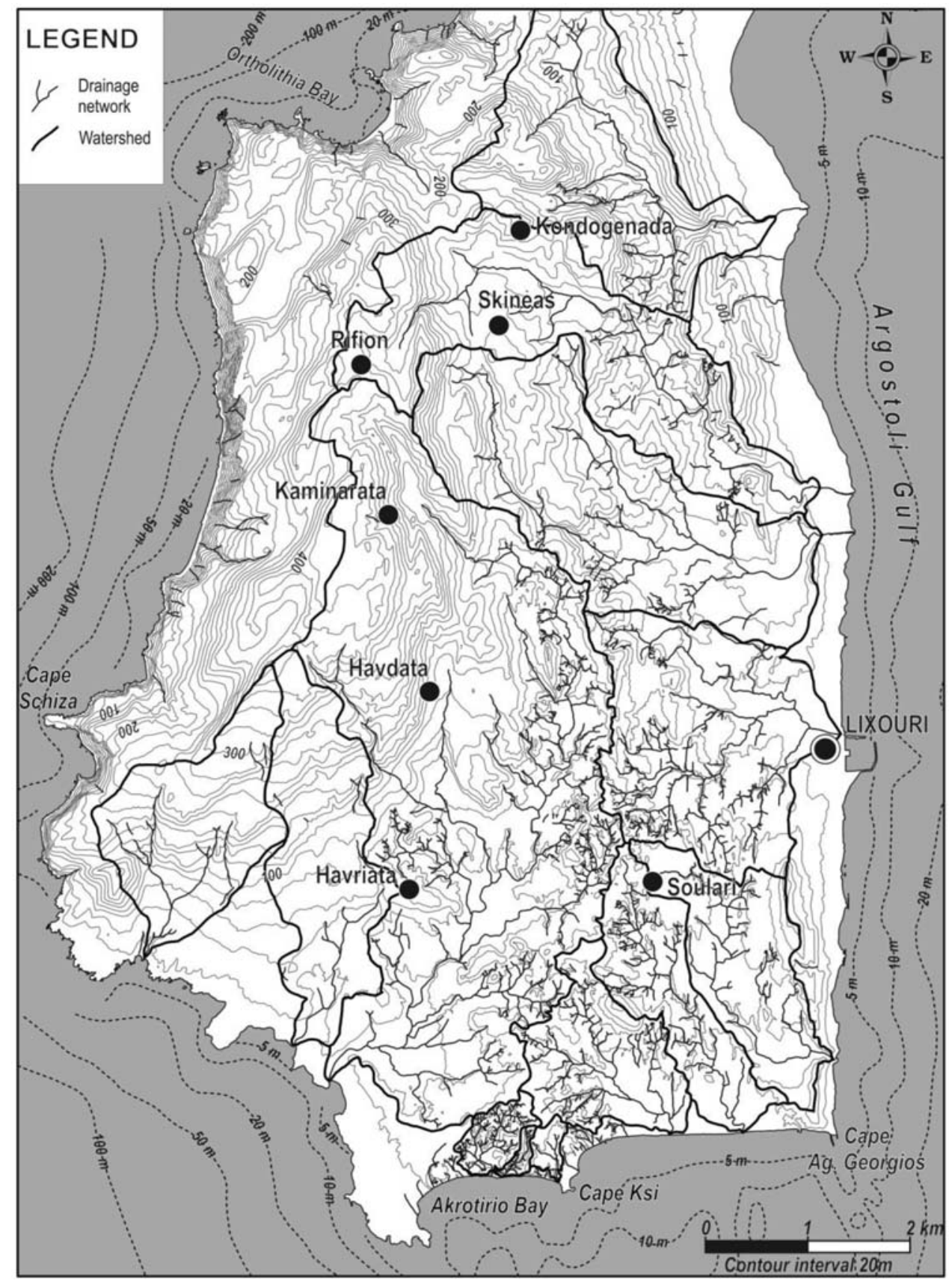

Fig. 3: Topographic map of the study area (Paliki Peninsula).

series of fine-grained sandstones and sandy marls reappear. The Pliocene formations occur in the southern and eastern part of the peninsula (Fig. 2). Along the eastern coast of the peninsula, sandstone formations are observed capping hills whose elevations reach $160 \mathrm{~m}$ and according to the ge- 
ological map of IGME (1985) their age is Tyrrhenian. Finally, the Holocene deposits are composed of scree, colluvial, fluvio-torrential and coastal sediments. Based on the raised marine deposits of the peninsula it becomes evident that the prevailing tectonic movement is positive (emergence) during the Pleistocene and Holocene periods.

The area is characterized by intense seismicity with strong and frequent earthquakes. During the last millennia two vertical displacements have been verified, which affected most of the island, associated with co-seismic uplift. The first occurred between 350 and $710 \mathrm{AD}$ and the second during the 1953 earthquake, which uplifted mainly the southeastern part of the island by 50 and $70 \mathrm{~cm}$ respectively (Pirazzoli et al., 1994; Stiros et al., 1994). Recent precise studies (Cocard et al., 1999; Hollenstein et al., 2006, Lagios et al., 2007) have confirmed the south-westward movement of the Ionian islands with a velocity of $7 \mathrm{~mm} / \mathrm{yr}$ increasing towards the south. A co-seismic horizontal displacement of the area of several $\mathrm{cm}$ and interseismic subsidence of up to $4 \mathrm{~mm} / \mathrm{yr}$ has also been found. The latter is in contradiction to the long term geological evidence of uplift, indicating that it is mainly a co-seismic result.

\section{Geomorphological analysis}

\subsection{Drainage systems}

The western slopes of the peninsula, where the older limestone formations occur, are drained by a few small, steep streams which flow directly into the Ionian sea. Thus this part of the study area is characterized by coarse drainage density. The northern half of the eastern part of the peninsula is drained by three major drainage networks with the upper reaches of their main channels flowing in a NNW-SSE direction and then turning to the east and emptying into the newly formed gulf of Argostoli. Two knickpoints were identified along the main channels of these three drainage systems. These knickpoints are evidence of two rejuvenation phases of the relief due to the tectonic uplift of the area. The uppermost parts of these drainage networks are the oldest as they have evolved on limestones of Eocene - Oligocene and Miocene age while their lowermost parts passing through the Pliocene deposits are much younger. These drainage networks were tributaries of a much larger drainage system which was active during the last glacial period up until early Holocene. The main channel of this drainage system had an almost N-S direction flowing along the eastern side of the present gulf of Argostoli which was a valley at that period.

At the southern part of the peninsula there are two drainage systems. Their upper parts have developed on limestone formations having a coarse drainage density while the more extensive lower parts drain Pliocene sediments. Additionally some drainage networks drain areas which consist exclusively of Pliocene formations. The main characteristic of these systems is the fine drainage density as a result of the high rainfall and the erodible character of the impermeable Pliocene lithologic sequence. Incision here is intense, especially where marls are present. It is clear that these are the most recent drainage networks of the study area that have evolved during the Quaternary period.

\subsection{Marine terraces}

Remnants of Quaternary marine terraces have been identified on Paliki peninsula as well as at other locations in the south and southeastern part of the island (Sorel, 1976). Detailed field geomorphological mapping revealed a sequence of eight marine terraces (Photos 1,2,3 and 4). The lower two terraces are the most continuous and well preserved and are located at elevations between 2-16 and 18-32 m respectively. They are present along the southern and eastern shoreline of the peninsula. 


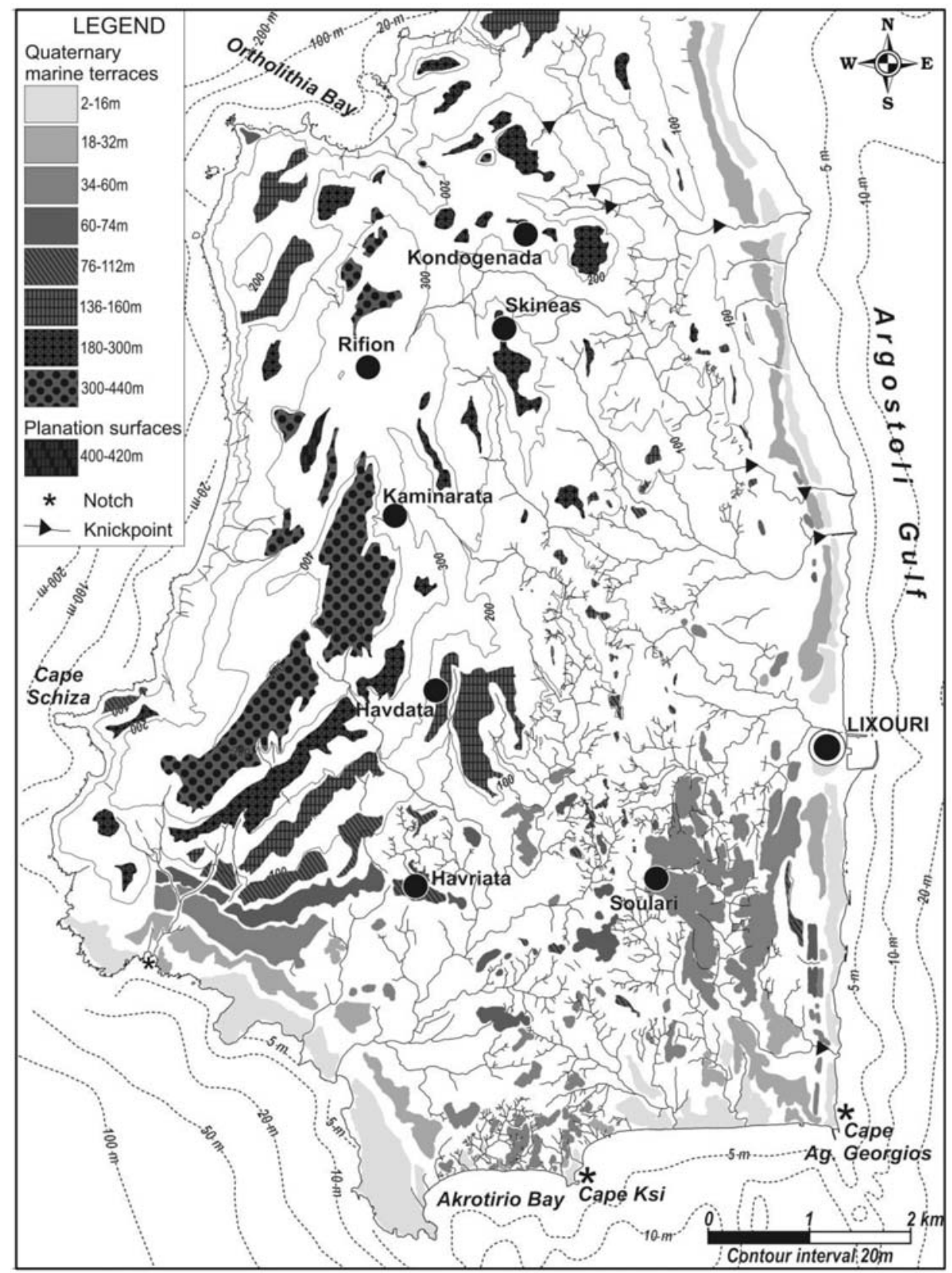

Fig. 4: Map of the Paliki peninsula showing the marine terraces and planation surfaces mapped in the field.

Remnants of higher marine terraces were distinguished at elevations between 34-60, 60-74, 76-112, 136-160, 180-300, 300-440 m respectively. The three higher marine terraces which have developed on Eocene-Oligocene limestones and are tilted to the southeast, seem to represent former shorelines carved during the Pliocene-Pleistocene. All these surfaces are incised by the channels of the drainage 


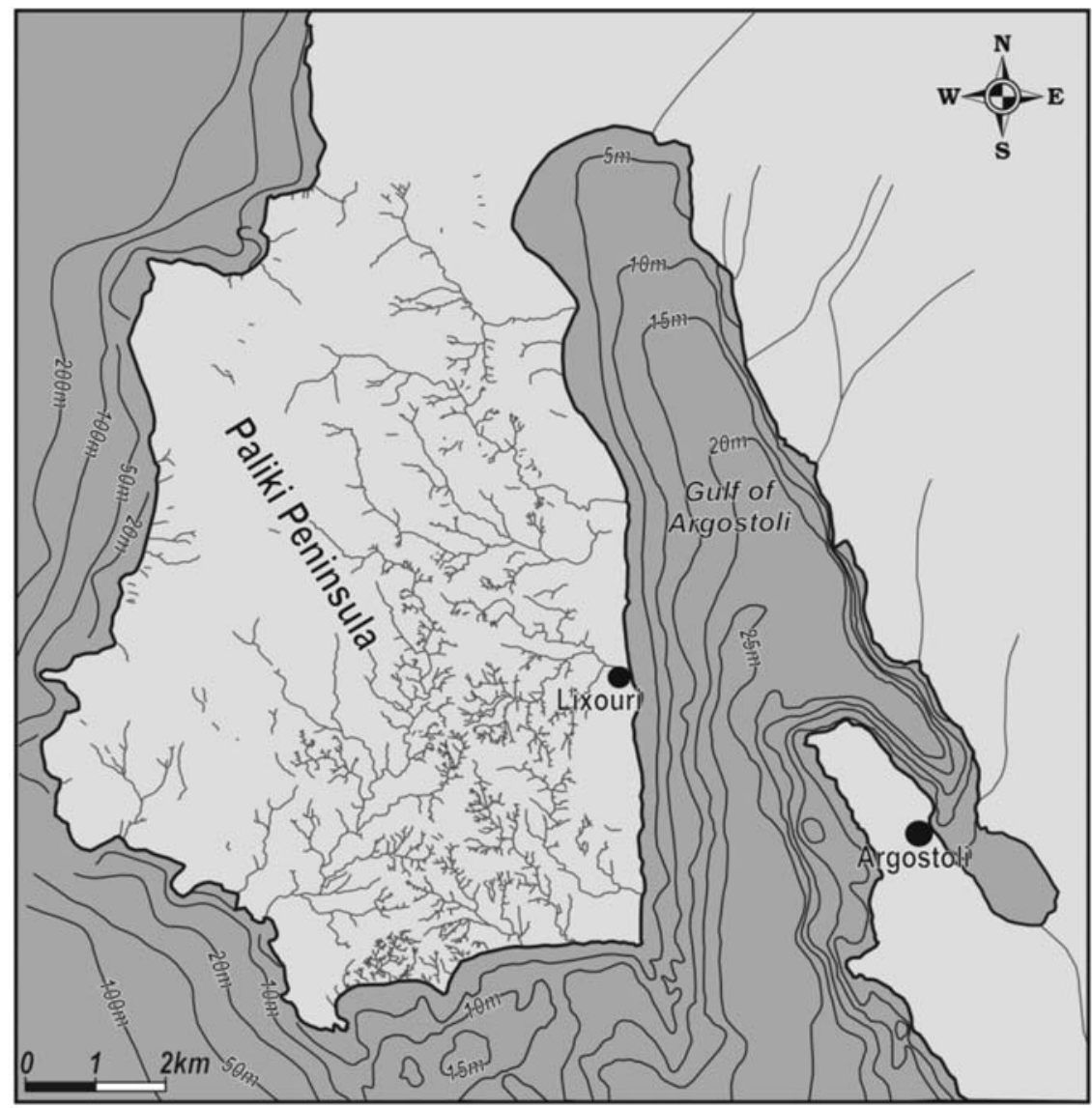

Fig. 5: Bathymetric map of the Argostoli gulf. Drainage networks of the Paliki peninsula are also depicted.

networks. The inner edges of some of the lower platforms were difficult to distinguish mainly due to the erodible lithology of the Pliocece formations.

\subsection{Coastal Geomorphology}

There are distinctly different geomorphic characteristics as well as geomorphic processes between the eastern and the western shores of the peninsula. The western coast is steep comprising limestone cliffs that reach a maximum height of about $240 \mathrm{~m}$. This part is subject to coastal erosion. On the other hand, the eastern coast is characterized by much lower slopes and sandy beaches. Three small fan deltas have formed at the mouths of the major drainage systems along the western shores of Argostoli gulf. The main reasons for these differences in the coastal geomorphology are the lithology as well as the tectonic regime of the island. The western coasts consist of hard to erode limestone formations while the eastern part is composed of erodible Pliocene formations. The bathymetry of the gulf of Argostoli reveals that it is a shallow submarine valley with a maximum depth of about $25 \mathrm{~m}$ east of cape Ag. Georgios, which was active until early Holocene. Its western submarine slopes are less steep than the eastern ones probably due to the deposition of sediments supplied by the drainage networks of the Paliki peninsula.

At the southern and southeastern shores of Paliki the presence of aeolianites and a notch at 1-2 $\mathrm{m}$ is 

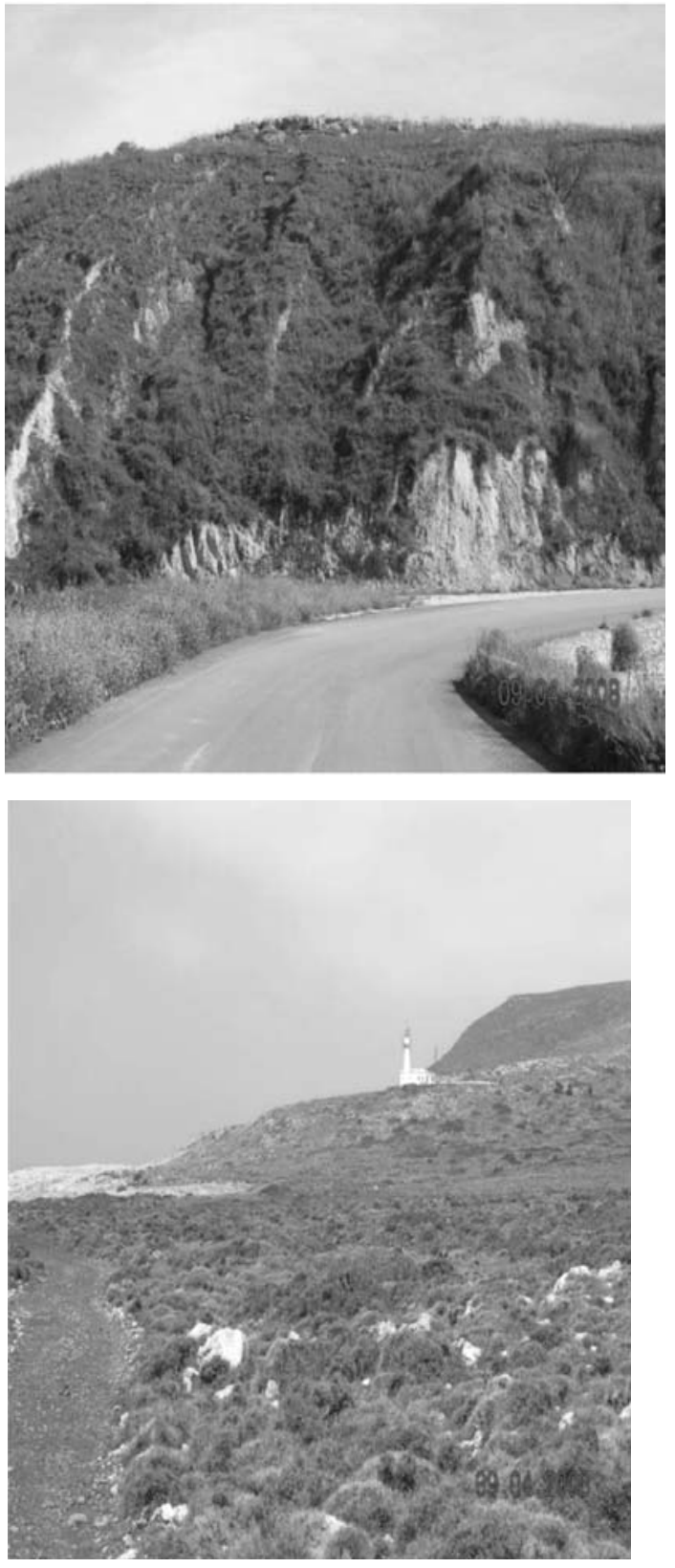

Photo 1.Pleistocene caprock overlying Pliocene blue marls.

Photo 2. Marine terraces at the southwestern edge of the study area.

also noteworthy. Almost the entire length of both the southern and eastern shoreline is made up by the two lower marine terraces.

\section{Palaeogeographic evolution - Conclusions}

Two generations of drainage systems were identified; an older coarse one which evolved on the carbonate formations and a younger finer one on the more recent Neogene formations. The initial flow 

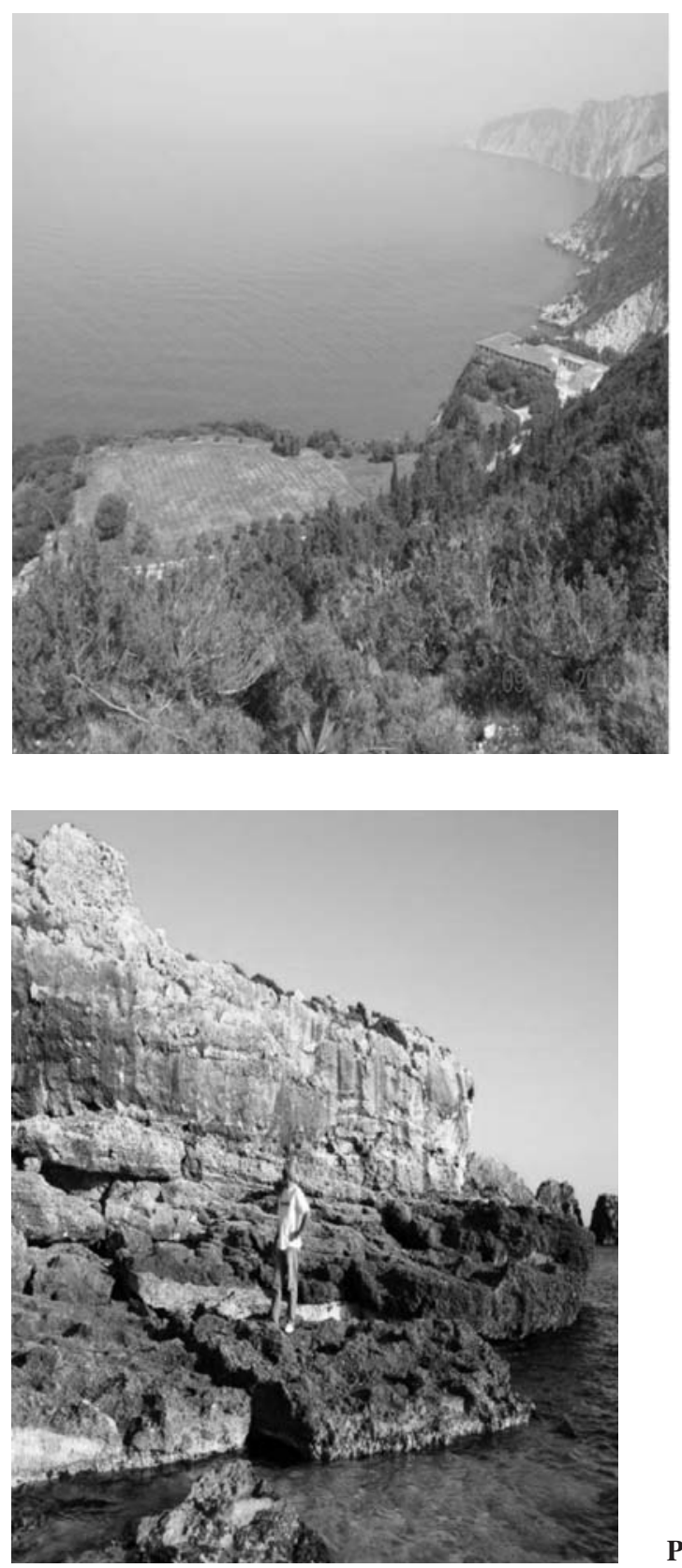

Photo 3. Marine terraces at $90 \mathrm{~m}$.

Photo 4. Raised beach at $3 \mathrm{~m}$ and marine terrace at $6 \mathrm{~m}$.

direction was to the south but in the Late Quaternary three major drainage systems changed direction towards the east flowing into the newly-formed gulf of Argostoli due to fault tectonism.

Different geomorphological features are observed in the western and the eastern shores of the peninsula mainly due to the lithology and the tectonic regime of the island. The western coasts consist of hard to erode limestone formations comprising steep faulted cliffs subject to intense coastal erosion 
while the eastern ones are composed of erodible Pliocene formations characterized by much lower slopes, sandy beaches and small fan deltas at the mouths of the major drainage systems.

Paliki peninsula was almost an island during the Pliocene period. From the beginning of the Pleistocene a gradual uplift of the area started raising the older limestone formations and creating a NNESSW slope of the carbonate platform where the first marine terraces were carved.

Eventually, the present Paliki peninsula was formed including the Pliocene formations and having a general N-S slope. The combination of eustatism and vertical tectonic movements has led to the development of eight uplifted marine terraces. A Late Holocene notch was also identified proving that the area is still uplifting. The marine terraces ranging in elevation from 2-16 to $300-440 \mathrm{~m}$ with the lower two terraces, at 2-16 and 18-32 m being the most continuous and well preserved. Finally, given that the oldest and highest shoreline is located at an elevation of $440 \mathrm{~m}$, and the Quaternary period lasted 2.6 million years the minimum long term uplift rate is estimated to be $0.17 \mathrm{~mm} /$ year.

\section{References}

British Petroleum Co. Ltd., 1971. The geological results of petroleum exploration in western Greece, Athens, Greece. Institute for Geological and Subsurface Research., Report No 10.

Cocard, M., Kahle, H.-G., Geiger, A., Veis, G., Felekis, S., Biliris, H. and Paradissis, D., 1999. New constrains on the rapid crustal motion of the Aegean region: recent results inferred from GPS measurements (1993-1998) across the West Hellenic Arc, Greece. Earth Planet. Sci. Lett., 172, 39-47.

Hollenstein, Ch., Geiger, A., Kahle, H.-G., and Veis, G., 2006. CGPS time-series and trajectories of crustal motion along the West Hellenic Arc. Geophys. J. Int., 164, 182-191.

Institute for Geological and Mining Research, IGME, 1985, Geological map of Kefalonia island. Scale 1:50000.

Lagios, E., Sakkas, V., Papadimitriou, P., Parcharidis, I., Damiata, B.N., Chousianitis, K., Vassilopoulou, S., 2007. Crustal deformation in the central Ionian islands (Greece): Results from DGPS and DInSAR analyses (1995-2006). Tectonophysics, 444, 119-145.

Louvari, E., Kiratzi,A.A., and Papazachos, B.C., 1999. The Cephalonia Transform fault and its extension to western Lefkada island (Greece). Tectonophysics, 308, 223-236.

Pirazzoli, P.A., Stiros, S.C., Laborel, J., Laborel-Deguen, F., Arnold, M., Papageorgiou and Morhange, C., 1994. Late Holocene shoreline changes related to palaeoseismic events in the Ionian Islands, Greece. The Holocene, 4, 397-405.

Scordilis, E., Karakaisis, G., Karakostas, B., Panagiotopoulos, D., Comninakis, P., and Papazachos, B., 1985. Evidence for Transform Faulting in the Ionian Sea: the Cephalonia Island Earthquake Sequence of 1983. Pure Appl. Geophys., 123, 388-397.

Sorel, D., 1976. Etude néotectonique des îles Ioniennes de Céphalonie et de Zante et de l' Elide occidentale (Grèce). These 3e cycle. University Paris Sud. Orsay.

Stiros, S.C., Pirazzoli, P.A., Laborel, J. and Laborel-Deguen, F., 1994. The 1953 earthquake in Cephalonia (Western Hellenic Arc): coastal uplift and halotectonic faulting. Geophys. J. Int., 117, 834-849.

Underhill, J., 1985. Neogene and Quaternary tectonics and sedimentation in Western Greece. PhD Thesis. University of Wales. 